\title{
Studies on the Tetraploid Flax Induced by Colchicine ${ }^{1}$ \\ By \\ Isao Masima \\ Hokkaido Imperial University
}

Feceical May 12, 1942

\section{Introduction}

On the artificial induction of polyploids by means of colchicine in Limum, many authors such as Simonnet (1938), Györfy (1938), Werner (1938), Rybin (1938), and Lutkov (1939) have already published papers. According to Lutkov (1938), the high temperature method is also available in Linum usitatissimum for this purpose.

It is an important and interesting problem to study the relation of chromosomes in the genus Linum, both from the cytogenetical and the practical points of view. This genus comprises many species that are different in chromosome numbers and in habits. Nagao $(1940,1941)$ has divided the species into five groups according to their chromosome numbers and to the results of crossing experiments. Moreover, L. usitatissimum is of practical use for its oil and fibre tissue, so breeding experiments have been widely made by many workers.

The present writer attempted to induce tetraploid Linum by the colchicine method. The previous authors who succeeded in inducing tetraploids in flax, have mainly carried out the treatment of young plant. Lutior (1939) had about $80 \%$ success in mass production of tetraploid flax. The present writer exclusively employed the seed immersion method exclusively for his investigation.

Here the writer wishes to express his obligation to Prof. S. Nagao for his guidance and encouragement given in this experiment and for his kindness in reading the manuscript.

\section{Material and Method}

The following species and vareities were used as materials, namely, L. angustifolium, L. crepitans, L. grandiflorum and two strains of a common cultivated species $L$. usitatissimum, one of which is a wilt resistant bred by the late Prof. Emeritus T. Minami of our university.

1 Contribution from the Plant Breeding. Institute, Faculty of Agriculture, Hoklaido Imperial University.

The essential points of this study were given before the 1st General Meeting of the Genetics Assoriation of Sapporo held in October, 1941. 
The writer carried out a preliminary experiment to find suitable concentration of colchicine and hours by which polyploid individuals may be effectively induced. In that experiment seeds of $L$. usitatissimum were immersed in $0.01,0.05,0.08$ and $0.1 \%$ aqueous solution of colchicine for 10 to 24 hours in thermostat at $25^{\circ} \mathrm{C}$ and then were washed in running water for 24 hours.

It became clear from the experiment that the treatment with $0.08 \%$ colchicine solution for 20 hours at $25^{\circ} \mathrm{C}$ gave the most positive results, accordingly that treatment was employed in the experiments described below. In stronger solutions than $0.08 \%$ young seedlings were immoderately swollen and they died.

\section{Results of Experiments}

\section{Observations of Plants from Treated Seeds}

The size of pollen grains, stomata and the external characteristics may be used expediently as criteria before cytological examinations whether the plant is a tetraploid or not, though these do not always coincide necessarily with the results of cytological views as Györffy (1941) has pointed out. The writer has selected by means of pollen comparison, some tetraploid plants which were considered to have been induced with colchicine treatment, the number of these plants being shown in Table 1.

Table 1. Effect of colchicine treatment

\begin{tabular}{|c|c|c|c|c|}
\hline Name of species & Treated seeds & $\begin{array}{l}\text { Germinating } \\
\text { seeds }\end{array}$ & $\begin{array}{l}\text { Swollen } \\
\text { seedlings }\end{array}$ & $\begin{array}{l}\text { Tetraplo d } \\
\text { plants }\end{array}$ \\
\hline $\begin{array}{l}\text { L. usitatissimum. } 1 \text {. } \\
\text { L. usitatissimum. } 2 . \\
\text { L. crepitans } \\
\text { L. angustifolium } \\
\text { L. grandiflorum }\end{array}$ & $\begin{array}{l}100 \\
100 \\
100 \\
100 \\
100\end{array}$ & $\begin{array}{l}87 \\
87 \\
75 \\
89 \\
72\end{array}$ & $\begin{array}{l}51 \\
83 \\
72 \\
71 \\
11\end{array}$ & $\begin{array}{l}5 \\
7 \\
2 \\
7 \\
-\end{array}$ \\
\hline
\end{tabular}

As shown in the above table, there can be found tetraploids in 3 species except $L$. grandiflorum. The treated plants in L. grandiflorum became very tall in stature and continued their vegetative growth until flowers began to open in the green house, in January next. The flowers were pink and paler in color than the normal red flower of this species. Further investigations could not be undertaken because no seeds were produced in these plants.

In the other three species these have been successfully obtained some tetraploids or mixoploids in Blakeslee's sense (Blakeslee 1941), in which a number of seeds were produced and morphological as well as cytological observations were carried out in filial plants grown from these seeds in the next year, 1941. 
In the treated parents, besides tetraploid progenies, there are found somewhat deformed types, namely, dwarf and non-flowering plants, lanky stemed plants and others. In some cases plants were vigorous and gigantic in size but pollen grains were not different at all in appearance from those of diploids. Some of these forms have been reported also by Lutkov (1939). It seemed possible to say that they were induced as the results of colchicine treatment.

\section{Observations on the Tetraploid Flax}

\section{(a) External characteristics}

In the second year of the experiment the writer obtained a number of tetraploid filial plants from the seeds which were produced in the treated species. In some of these tetraploids the double number of chromosomes, $2 n=60^{1}$ can be actually ascertained cytologically (Figs. 8-9), while in other cases the plants have been presumed to be tetraploid or at least $\pm 4 \mathrm{x}$ from their external characteristics.

Since tetraploid plants usually show retardation of germination and growth, at the beginning they seem to be rather smaller than the diploid plants as seen in Figs. 1-3, but at the end of the growing period the tetra-
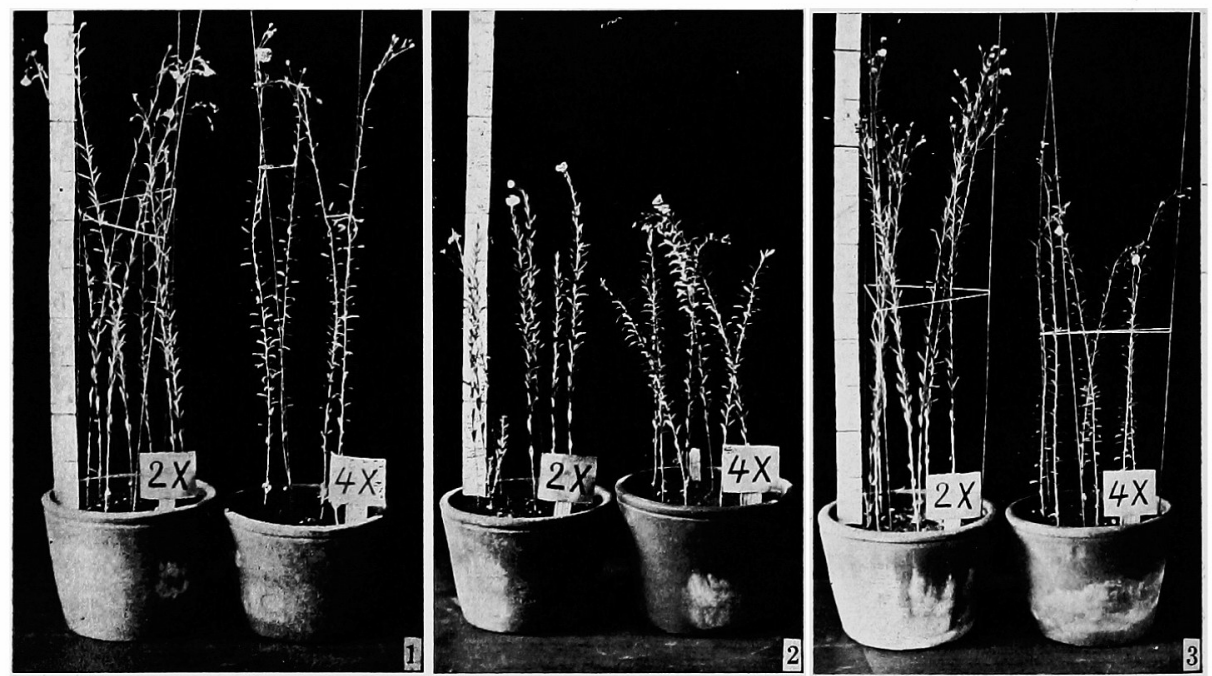

Figs. 1-3. Diploid and tetraploid plants of the three species of Linum in blooming period. (1) L. usitatissimum, (2) L. angustifolium, (3) L. crepitans.

ploid plants become more vigorous and taller, showing a gigantic appearance where pale green thick leaves, large and roughly branching stems are noticeable. Pollen grains, stomata, and capsules as well as seeds

1. The diploid chromosome numbers of plants which were used in this experiment were 30 in all. 
which were shrivelled and flat were also observed to be larger in tetraploids than those of the diploids (Figs. 4-7). Flower buds were formed much

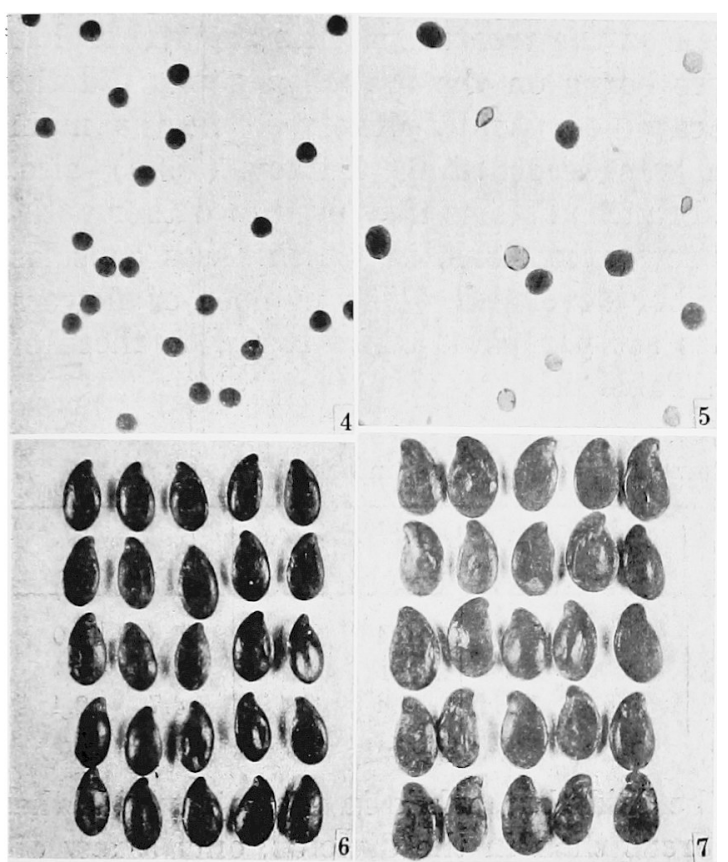

Figs. 4-7. Comparison of pollen grains and seeds in $L$. usitatissimum. Pollen grains of diploid (4) and tetraploid (5), seeds of diploid (6) and tetraploid ,7). phologically by acetocarmine smear method. The number of fertile pollen more abundantly in number in tetraploids in comparison with those of diploids. Numerical comparisons were made on some other characters as shown in Table 2 (cf. also Table 4).

From Table 2 it is clearly noted that the tetraploids are more or less slower in their vegetative growth, though more vigorous than the diploids.

In L. usitatissimum, not infrequently there can be observed some deformed flowers with small or superfluous petals.

\section{(b) Fertility}

The fertility of pollen grains was examined mor-

Table 2. Comparison of diploids and tetraploids (glass house cultivation)

\begin{tabular}{|c|c|c|c|c|c|c|}
\hline \multicolumn{2}{|l|}{ Name of species } & $\begin{array}{l}\text { Height of } \\
\text { plant }\end{array}$ & $\begin{array}{l}\text { Dry weight } \\
\text { of plant }\end{array}$ & $\begin{array}{l}\text { Days of ger- } \\
\text { mination }\end{array}$ & $\begin{array}{c}\text { Duration of } \\
\text { growing }\end{array}$ & $\begin{array}{l}\text { Days of } \\
\text { flowering }\end{array}$ \\
\hline L. usitatissimum 1. & $\begin{array}{l}2 \mathrm{x} \\
4 \mathrm{x}\end{array}$ & $\begin{array}{l}60.60 \mathrm{~cm} \\
66.39\end{array}$ & $\begin{array}{l}0.46 \mathrm{~g} . \\
0.72\end{array}$ & $\begin{array}{l}5.6 \\
7.0\end{array}$ & $\begin{array}{l}75 \\
98\end{array}$ & $\begin{array}{l}25 \\
31\end{array}$ \\
\hline L. usitatissimum 2. & $\begin{array}{l}2 \mathrm{x} \\
4 \mathrm{x}\end{array}$ & $\begin{array}{l}59.00 \\
68.60\end{array}$ & $\begin{array}{l}0.64 \\
080\end{array}$ & $\begin{array}{l}5.5 \\
7.0\end{array}$ & $\begin{array}{l}75 \\
98\end{array}$ & $\begin{array}{l}26 \\
34\end{array}$ \\
\hline L. crepitans & $\begin{array}{l}2 x \\
4 x\end{array}$ & $\begin{array}{l}51.15 \\
61.51\end{array}$ & $\begin{array}{l}0.59 \\
0.61\end{array}$ & $\begin{array}{l}5.8 \\
7.0\end{array}$ & $\begin{array}{l}75 \\
98\end{array}$ & $\begin{array}{l}26 \\
39\end{array}$ \\
\hline L. angustifolium & $\begin{array}{l}2 \mathrm{x} \\
4 \mathrm{x}\end{array}$ & $\begin{array}{l}45.15 \\
48.15\end{array}$ & $\begin{array}{l}0.67 \\
0.70\end{array}$ & $\begin{array}{l}5.5 \\
6.0\end{array}$ & $\begin{array}{l}75 \\
98\end{array}$ & $\begin{array}{l}23 \\
40\end{array}$ \\
\hline
\end{tabular}

Average of 20 plants except L. crepitans where 10 plants were used for observations.

Table 3. Comparison of fertile pollen grains of $2 \mathrm{x}$ and $4 \mathrm{x}$ Linum

\begin{tabular}{l|c|c|c|c}
\hline & L. usit. 1. & L. usit. 2. & L. crepitans & L. angust. \\
\hline Diploid & $96.58 \%$ & $93.28 \%$ & $97.64 \%$ & $97.64 \%$ \\
Tetraploid & 64.88, & $60.11,$, & $66.72 \%$ & $74.73 \%$
\end{tabular}


grains which were not shriveled but normal in shape were counted, the results being shown in Table 3.

The fertility of seed, that is, seed setting were also examined. In the filial tetraploid plants as well as the treated parents the writer has observed that only in the flowers borne on the branched stems did the capsules develop, however, no capsules usually developed in the main stems. A similar phenomenon was recorded by Lutkov (1939) also. Even in the flowers borne on the branched stems they used to wither without developing capsules with a few exceptions, in which cases capsules having only a few seeds in number developed. The number of flowers bloomed and that of the capsules set per plant compared with those of the diploids are recorded in the Table 4.

Table 4. Number of flowers and capsules set in one plant

\begin{tabular}{|c|c|c|c|c|c|c|c|c|}
\hline & \multicolumn{2}{|c|}{$\begin{array}{l}\text { L. usit. } 1 \\
2 \mathrm{x}\end{array}$} & \multicolumn{2}{|c|}{$\begin{array}{l}\text { L. usit. } 2 . \\
2 \mathrm{x}\end{array}$} & \multicolumn{2}{|c|}{ L. crepitans } & \multicolumn{2}{|c|}{ L. angust. } \\
\hline $\begin{array}{c}\text { Number of flowers } \\
\text { bloomed }\end{array}$ & 6.8 & 14.4 & 6.1 & 10.1 & 6.4 & 13.4 & 6.6 & 10.0 \\
\hline $\begin{array}{c}\text { N..mber of capsules } \\
\text { set }\end{array}$ & 3.1 & 1.0 & 3.5 & 1.7 & 4.4 & 2.4 & 4.7 & 2.4 \\
\hline
\end{tabular}

Generally speaking, it may be said that, while in the tetraploids the blooming flowers are more numerous than in the diploids, only a few of them develop capsules. Thus we may estimate the fertility of a plant through the following formula, the results obtained by this calculation being shown in Table 5 .

$$
\begin{aligned}
& \text { Fertility }\left(0^{\prime}\right)=\frac{\text { Total capsules } \times \text { seeds per one capsule }}{\text { Total flowers bloomed } \times 10^{*}} \times 100 \\
& * 10 \text { is the number of seeds in normal grown capsule. }
\end{aligned}
$$

Table 5. Comparison of fertility in $2 \mathrm{x}$ and $4 \mathrm{x}(\%)$

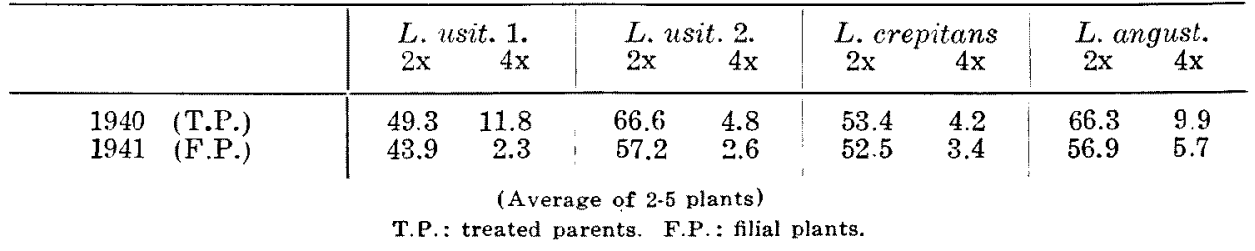

As seen from Table 5, fertility of the diploids is not very high, perhaps due to the cultural conditions in the glass house, yet in any cases, in the induced tetraploids than that of the diploids.

Fertility of the filial generation plants was lower than that of the treated parents, though the reasons therefor remain in obscurity. 


\section{(c) Cytological investigations}

Because of fewer materials in the treated parents, cytological studies were carried out exclusively in the filial generation plants.

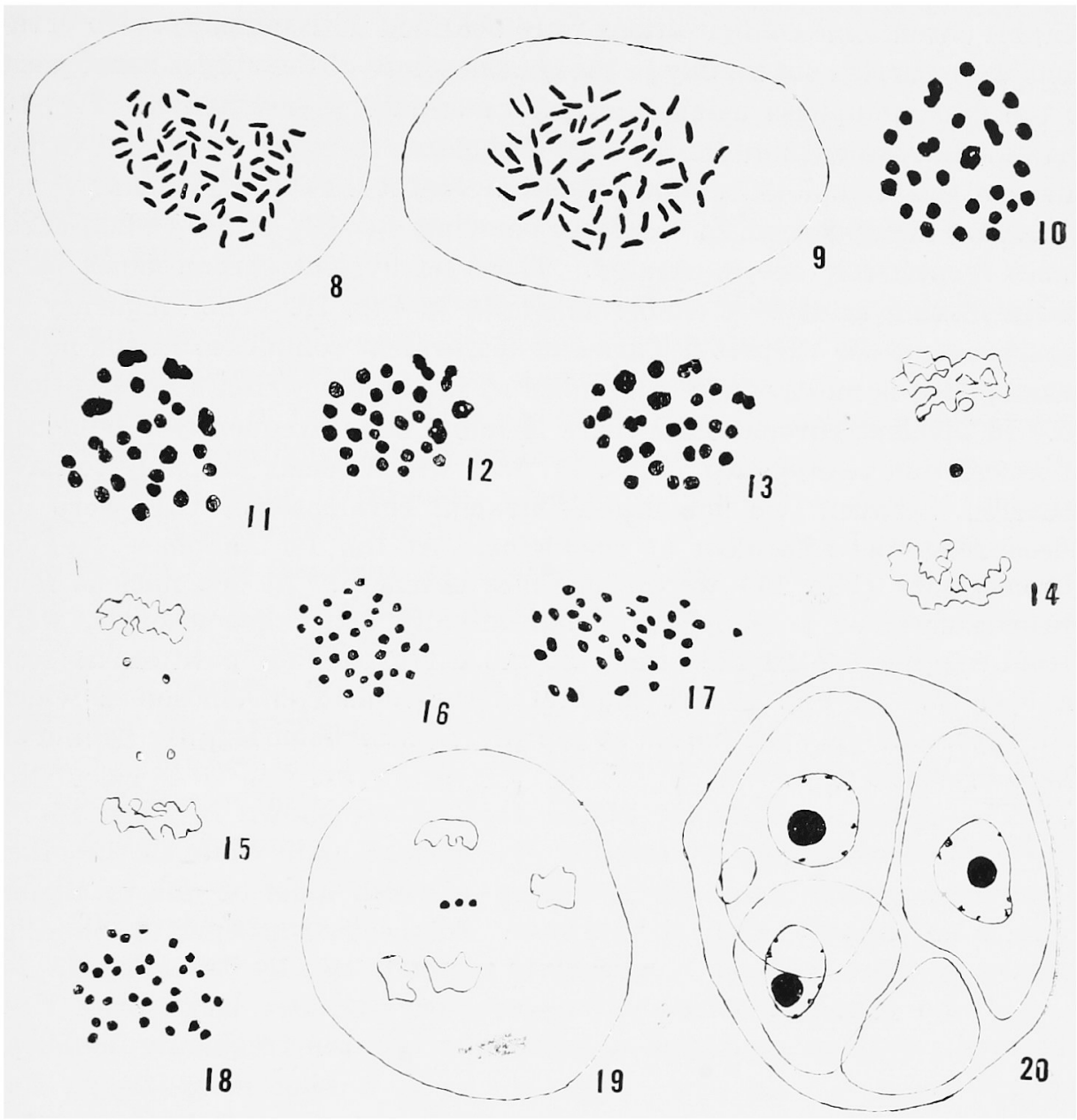

Figs. 8-20. Chromosomes in somatic and meiotic divisions. 8. Somatic chromosomes of $4 \mathrm{x}$ L. usitatissimum 1. $(2 \mathrm{n}=60)$. 9. The same in $4 \mathrm{x} L$. angustifolium $(2 \mathrm{n}=60)$. 10. Meiotic nuclear plate of $4 \mathrm{x}$ L. crepitans, showing $4 \mathrm{IV}+22_{\mathrm{II}}$. 11. The same in $4 \mathrm{x}$ L. crepitans showing $4 \mathrm{IV}+22 \mathrm{II}$. Tendency of association is observed in some chromosomes. 12. The same in $4 \mathrm{x}$ L. angustifolium showing $44_{\mathrm{IV}}+22_{\mathrm{II}}$. 13. The same in $4 \mathrm{x}$ L. crepitans showing $5_{\text {IV }}+20 \mathrm{II}$. 14. Lagging chromosomes at the 1st anaphase of $4 \mathrm{x} L$. crepitans. 15. The same, showing two split halves migrating between the poles. 16. Nuclear plate in the second division of $L$. crepitans, sbowing 30 chromosomes. 17 . The same, showing 32 chromosomes. 18. The same; tendency of association is noticeable two by two. 19. Second anaphase of $4 \times$ L. crepitans, showing 3 laggards. 20. Abnormal tetrad. 8-20, except 19, $\times 2500$. 19, $\times 1500$.

Chromosome numbers of the somatic cells were determined to be 60 as shown in Figs. 8-9. For the study of meiotic chromosomes, young- 
flower buds were fixed by the Carnoy-Navashin method, cut 15 micra thick, and stained with Heidenhain's haematoxylin or Randolph's iodinecrystal-violet method, the latter being most suitable for observations. Though many buds were fixed in each species for each separate plant, suitable chromsome configurations were obtained with difficulty. Observations were carried out mainly in the chromosomes at the stages subsequent to the first metaphase using L. crepitans and L. angustifolium. Fig. 10 shows 4 tetravalent and 22 bivalent chromosomes found in the 1 st metaphase of the tetraploid $L$. angustifolium. In Figs. 11 and 13, polar views of the 1 st metaphase in $L$. crepitans showing $4_{\mathrm{IY}}+22_{\mathrm{II}}$ and $5_{\mathrm{I}}+20_{\mathrm{II}}$ chrosomes respectively are illustrated. These tetravalent chromosomes were of closed ring or of four chains as shown in Fig. 12. The frequency of occurrence of the various numbers of tetravalent complexes in the metaphase plates is mostly four in number so far as the writer's observations go. In bivalent chromosomes there is found not infrequently a tendency of association two by two (Figs. 11, 13), which seems probably to have occurred, between two homologous bivalent chromosomes that were induced from the treatment of colchicine. At the 1st anaphase lagging chromosomes (Fig. 14) were sometimes observed. In one nucleus four chromosomes, or possibly two longitudinally split chromosomes, were found lagging behind the others at the corresponding position as seen in Fig. 15. In Fig. 19 are illustrated the monad chromosomes which will represent the split halves at the previous division lagging behind in the achromatic area.

The chromosomes in the 2nd metaphase are shown in Figs. 16-18, where 30 chromosomes are counted in a nuclear plate while in the other plate there are countable 32 chromosomes which must be due to an unequal distribution at the 1 st anaphase. In the chromosomes of the 2 nd metaphase there is found a tendency to associate two by two (Fig. 18).

In the telophase micro-nucleus or nuclei besides large ones were observed, and irregular pollen tetrads were also frequently observed (Fig. 20).

\section{Discussion}

Since Blakeslee and Avery's discovery in 1937, artificially induced polyploid plants have been successfully obtained in Linum also. Simonet (1938) by treating seeds in 0.1-0.4\% colchicine solution for 2 days, obtained polyploid individuals in L. usitatissimum. Györffy (1938) induced tetraploid flax by the treatment of young plants in $0.01-0.5 \%$ colchicine solutions. Werner (1938) treated seed but did not obtain positive results. Rybin (1938) induced tetraploid flax in $0.1 \%$ solution. According to Lutokov $(1938,1939)$, the tetraploid plants were obtainable 
by subjecting zygote of flax to high temperature or by treating the meristematic region of young plants with colchicine solution. By the latter method a large number of polyploid plants amounting up to $80 \%$ being induced in the species, $L$. usitatissimum, L. angustifolium, L. prenne and $L$. grandiflorum.

Though the methods are different as employed by different authors, it has been clearly ascertained that it is possible to induce polyploids by colchicine treatment. The present writer also succeeded to induce tetraploid plants in 3 species of annual flaxes by treating seeds in colchicine. Suitable method of treatment was in $0.08 \%$ colchicine solution for 20 hours at $25^{\circ} \mathrm{C}$.

The morphological characters of tetraploid plants are of gigas types which are usually the case in polyploids investigated by previous authors such as Wettstein (1924) in moss, and many others.

The fertility of tetraploids is one of the most important and interesting problems especially in application to plant breeding. It is generally known that in many tetraploids, whether naturally found or artificially induced, a characteristic infertility occurs, the reason for which Darlington assumed to be the irregular segregation of multivalent chromosomes ( $c f$. Darlington 1937). Müntzing (1936) has re-examined many examples of polyploid plants and ascertained that natural selection has an important role in the natural polyploids where no reduced fertility is found in contrast to the experimental polyploids.

In the present experiments, the fertility of pollen grains amounts to $60-70 \%$, however, the fertility as seen from seed setting was much reduced, being $2-10 \%$ in value. Though the reason for the difference between fertility of pollen grains and the seed sets is left for further investigations, it may be of significance that in the tetraploids flowers frequently fall off early without developing capsules. The tendency of dropping is much stronger in the tetraploids than that in the diploids. It seems possible to consider that this phenomenon in the tetraploids is due to some physiological conditions, in connection with the doubling of chromosomes, while this may be occurred in some cases by environment effect.

\section{Summary}

1. By treatment with $0.08 \%$ colchicine solution in 20 hours at $25^{\circ} \mathrm{C}$ tetraploid plants were induced in $2-5 \%$ of the treated seeds in 3 species: Linum usitatissimum, L. angustifolium and L. crepitans.

2. These tetraploid plants were of gigas types having tall stems and thick leaves. Size of pollen grains, flowers, capsules as well as seeds were also larger than those of the diploid plants. Retardation of growth in comparison with the diploids was usually observed. 
3. In tetraploids the mean fertility of pollen grains was 60-70\% in value, however, the number of seed set was considerably smaller amounting 2-10\%, mainly because many flowers dropped down before capsules developed.

4. Chromosome behaviour was also examined. The configuration $4_{\mathrm{IV}}+22_{\mathrm{I}}$ was commonly found at the 1 st metaphase in L. crepitans. In anaphase, lagging chromosomes were frequently observed. Unequal distribution of chromosomes were suggested from the counting of them at the second metaphase.

\section{Literature Cited}

Blakeslee, A. F. and A. G. Avery 1937. Method of inducing doubling of chromosomes in plants by treatment with colchicine. Jour. Hered. 28.

Blakeslee, A. F. 1941. Effect of induced polyploidy in plants. Amer. Nat. 75.

Darlington, C. D. 1937. Recent advances in cytology. 2nd ed. London.

Györfy, B. 1938. Durch Colehicinbehandlung erzeugte polyploide Pflanzen. Naturwiss. 26.

- 1940. Die Colchicinmethoder zur Erzeugung polyploide Pflanzen. Zïchter 12.

Kostoff, D. 1941. Polyploidy and its role in evolution and plant breeding. Mini. Agri. Aut. Agri. Res. Inst. Sofia, Bulgaria.

Levan, A. 1938. The effect of colchicine on root mitosis in Allizm. Hereditas 24.

- 1939. The effect of colchicine on meiosis in Allium. Hereditas 25.

Lutkov, A. N. 1938. Tetraploidy in Linum induced by high temperature treatment of the zygote. C. R. Acad. Sci. URSS. 19.

- 1939. Mass production of tetraploid flax plants by colchicine treatment. C. R. Acad. Sci. URSS. 22.

Müntzing, A. 1936. The evolutionary significance of autopolyploidy. Hereditas 21.

Nagao, S. 1940. Cytogenetic studies on the genus Linum. 2. Affinity among species as seen from the relation of chromosomes. (In Japanese). Agricul. \& Horticul. 15.

- 1941. Cytogenetics in the genus Linum. Jap. Jour. Genet. 17.

Rybin, V. A. 1938. Colchicine inducing tetraploidy in flax. C. R. Acad. Sci. URSS. 21.

Simonnet, M., Chopinet, R. et Souilijiert, G. 1938. Sur l'obtention d'un Linum usitatissimum, L. tetraploide, aprés application de colchicine. C. R. Séa. Acad. Sci. 207.

Werner, G. 1839. Untersuchungen úber die Möglichkeit der Erzeugung polyploider Kulturpflanzen durch colchicinbehandlung. Züchter 11.

Wettstein, F. 1924. Morphologie und Physiologie des Formwechsels der Moose auf genetischer Grundlage. I. Zeits. ind. Abst. Vererb. 33. 